\section{Quake aid hampered by ban on web shots}

\section{Open-access satellite images} are revolutionizing responses to disasters. Yet the government of Pakistan has forced aid agencies to remove pictures of earthquake devastation from the Internet.

Three days after the 7.6-magnitude earthquake struck Kashmir on 8 October, the Pakistan government appealed for high-resolution satellite images to help relief efforts. But, apparently to protect national security, Nature has learned that the government has since forced international agencies and relief organizations to remove these images from their websites.

The International Charter on Space and Major Disasters put high-resolution images of the earthquake zone on its website last Friday, then pulled them off hours later. The charter, a consortium of space agencies, was created in 2000 to supply satellite images and data to communities in need of relief following a disaster.

An International Charter spokesperson said: ${ }^{\alpha}$ To best aid relief efforts, we are no longer publicly disseminating pictures of the Pakistan earthquake. Publication of such images would compromise the ability of United Nations (UN) forces on the ground to deliver relief. We hope you understand the situation."

But a senior official at the charter, who asked not to be named, says that the Pakistan government had demanded that no photos be made accessible to the public, because it feared the images could compromise security in the Kashmir region - an area that has long been disputed territory between India and Pakistan. The UN and other aid agencies need Pakistan's cooperation on the ground, and had no choice but to comply, he says.

The UN, European Union (EU) and other international agencies have a general policy of making all such images publicly available. But

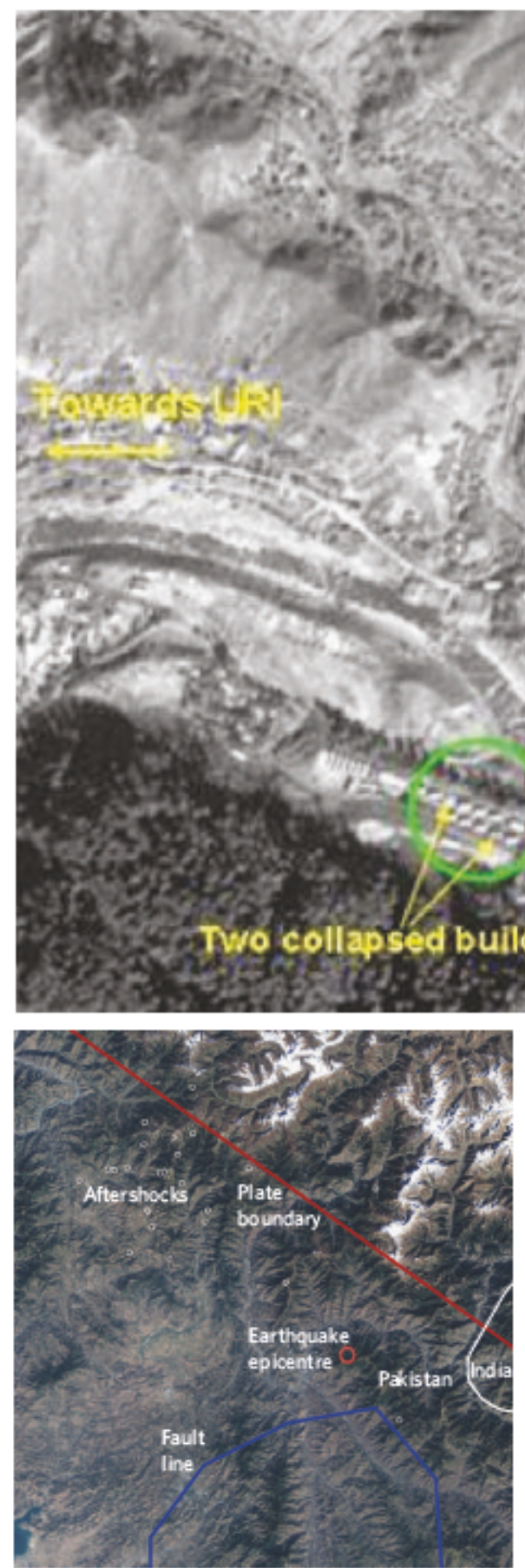

last week photos of the quake zone disappeared from sites such as the UN's ReliefWeb and satellite imaging site UNOSAT, and Reuters' AlertNet. On others they became passwordprotected, such as on the EU's disasters site. Images of the earthquake zone will now be distributed on a "need to know" basis to affiliated relief organizations, says a senior EU official.

Although the main organizations can still access the data, the pulling of the images is "regrettable", says the official, who asked not to
Images of the devastation in Kashmir caused by the earthquake in Pakistan couldhelp direct relief efforts, buthigh-resolution shots of the area (above) were removed from public websites.

be named. The images are useful to other local aid organizations, and to professionals worldwide who help out using the Internet, the official points out.

\section{Scene from above}

The Citizens Foundation, for example, a wellrespected Pakistan organization based in Karachi, is providing basic care packages including tents, blankets and food rations to those affected. But Ayaz Abdulla, a mechanical engineer from Karachi who coordinates Internet-based parts of the local relief effort, and others at the organization, spent much of last week desperatelye-mailing space agencies and commercial suppliers, to try to obtain images.

${ }^{\alpha}$ We look for major areas of dense devastation that correspond to higher population, and for access roads to allow relief-goods transport," Abdulla says. The images are used to plan logistics, work out what roads are open, and locate isolated settlements.

The importance of publidy available satellite images and other geographical data was 
